\title{
Comparison between Rectal Bromocriptine and Oral Cabergoline in Treatment of Hyperprolactinemia
}

A.Y.Rezk, A.A.Abd El- Hameed, T.M.Assar and A.K.Abbas

Obstetrics and Gynecology Dept., Faculty of Medicine, Benha Univ., Benha, Egypt

E-Mail:ahmed2356@gmail.com

\begin{abstract}
This examination analyzed between oral cabergoline and rectal bromocriptine in the treatment of female patients experiencing. This investigation was directed on 220 female patients experiencing hyperprolactinemia with whose serum prolactin level over $25 \mathrm{ng} / \mathrm{ml}$. A definite history taking, clinical assessment and serum prolactin level were done to all members. patients were isolated into two gatherings in a randomized example; gathering (a), included 110 patients were treated with $2.5 \mathrm{mg}$ bromocriptine rectally day by day once as long as 3 months.; gathering (b), included 110 patients were treated with oral cabergoline.1/2 tablet two times per week as long as 3 months. Prolactin level was tested before treatment then following a month and 4 months individually, contrasting prolactin level pre-and post-treatment, there was huge abatement in prolactin level after treatment in Bromocriptine gathering (mean prolactin= 16.5 versus 40, $\mathrm{p}<0.001$ ); just as in Cabergoline gathering (mean prolactin= 11.3 versus $41, \mathrm{p}<0.001$ ). Cabergoline bunch after treatment had altogether lower prolactin level when contrasted with Bromocriptine gathering $(p<0.001)$. Change in prolactin level after treatment contrasting with pattern level was determined, Cabergoline bunch demonstrated essentially higher rate change in prolactin level when contrasted with Bromocriptine gathering (mean rate change $=64.9 \%$ versus $55 \%, \mathrm{p}<0.001$ ). Delineating cases into intermittent and non-repetitive hyperprolactinemia, uncovered that those with non-repetitive hyperprolactinemia, cabergoline bunch had fundamentally lower level when contrasted with bromocriptine gathering (11.3 versus $13.5, \mathrm{p}<0.001)$. While those with intermittent hyperprolactinemia, bromocriptine and cabergoline bunches had non-critical distinction in prolactin level at 4 months after treatment ( $>0.05)$. Treatment with Cabergoline had fundamentally lower prolactin level when contrasted with Bromocriptine bunch at about a month and 4 months.
\end{abstract}

Keywords : Hyperprolactinemia, Cabergoline, Bromocriptine.

\section{Introduction}

Hyperprolactinemia is a regular reason for regenerative issues experienced in clinical practice; assortment of pathophysiological conditions can prompt hyperprolactinemia [20].

In ladies, a high blood level of prolactin frequently causes hypoestrogenism with anovulatory fruitlessness and a lessening in period. In certain ladies, period may vanish inside and out amenorrhea. In others, feminine cycle may become sporadic or feminine stream may change. Ladies who are not pregnant or nursing may start delivering bosom milk [15].

Bromocriptine is subordinate of lysergic corrosive subbed with bromine that ties to dopamine-D2receptors. The dopamine agonist, bromocriptine mesylate, is frequently the underlying medication of decision and may require high portions to accomplish clinical improvement and shrinkage of prolactinomas. It can bring down the prolactin level in $70-100 \%$ of patients it is a helpful device in the treatment of hyperprolactinemia [11].

Bromocriptine is accessible in the market as oral tablets and cases, just $28-30 \%$ of the oral portion is ingested. The oral bioavailability is just $4.5-6 \%$ in view of broad pre-fundamental digestion by the liver. Notwithstanding unfriendly results, generally being postural hypotension, sickness, regurgitating, exhaustion, migraines, discombobulation and faintness in half to $70 \%$ of ladies, causing about $10 \%$ end treatment [17].

Cabergoline is an ergot subsidiary which is longacting dopamine agonist that is viable and very much endured in patients with neurotic hyperprolactinemia
[13]. Cabergoline invigorates halfway found dopaminergic receptors bringing about various pharmacologic impacts. Cabergoline can treat manifestations related with sporadic monthly cycle, undesirable bosom milk creation, fruitlessness, bone misfortune, and sexual issues. As with bromocriptine treatment, queasiness and discombobulation are conceivable results however might be kept away from if treatment is begun gradually [11].

The point of the Work was to look at the clinical adequacy, results and bearableness of rectal Bromocreptine when contrasted with oral Cabergoline tablets for treating hyperprolactinemia.

\section{Patients and methods}

A similar report directed on two hudered and twenty females assembled from the Gynecology and obstetrics outpatient's facilities at Benha University Hospital, during the period between April 2018 till January 2020. The consideration measures of the examination bunch were cases Patients in youngster bearing period (18-38) years of age with manifestations recommending hyperprolactinemia: galactorrhea. feminine unsettling influences and patient's looking for richness essential or auxiliary and patients who didn't take any prolactin normalizing drug. While ladies with different reasons for fruitlessness as male factor or tubal factor, ladies with other as thyroid brokenness, liver cell disappointment, renal disappointment and ladies who were lactating were prohibited from the work. Endorsement of the Research Ethical Committee was conceded prior to beginning the investigation. 
The member ladies had been randomized by PC created arbitrary numeric table. The arbitrary distribution arrangement was disguised in fixed dull envelope then patients have been doled out arbitrarily into Group1: 110 patients who got $2.5 \mathrm{mg}$ bromocriptine rectally every day once for a very long time. Group2: 110 patients who got oral cabergoline $1 / 2$ tablet two times every week for a very long time. Prolactin level was measured before treatment then following a month and 4 months separately.

\section{Statistical analysis}

The collected data was revised, coded, tabulated and introduced to a PC using Statistical package for Social Science (IBM Corp. Released 2017. IBM SPSS Statistics for Windows, Version 25. Armonk, NY: IBM Corp.). The results were shown in tables \& figures, collected data was statistically represented in terms of range, mean, standard deviation $(+\downarrow-$ SD) and percentage.

\section{Results}

A randomized controlled comparative clinical trial was conducted to evaluate and compare the efficacy of two different modalities in the treatment of hyperprolactinemia, 242 cases of hyperprolactinemia were assessed for illegibility; 22 were excluded because they didn't fulfill the inclusion criteria. All 220 participants were enrolled in the study; patients were divided into two groups in a randomized pattern; group (a), included 110 patients were treated with 2.5 $\mathrm{mg}$ bromocriptine rectally daily once up to 3 months.; group (b), included 110 patients were treated with oral cabergoline.1/2 tablet twice a week up to 3 months. Prolactin level was assayed before treatment then after 4 weeks and 4 months respectively.

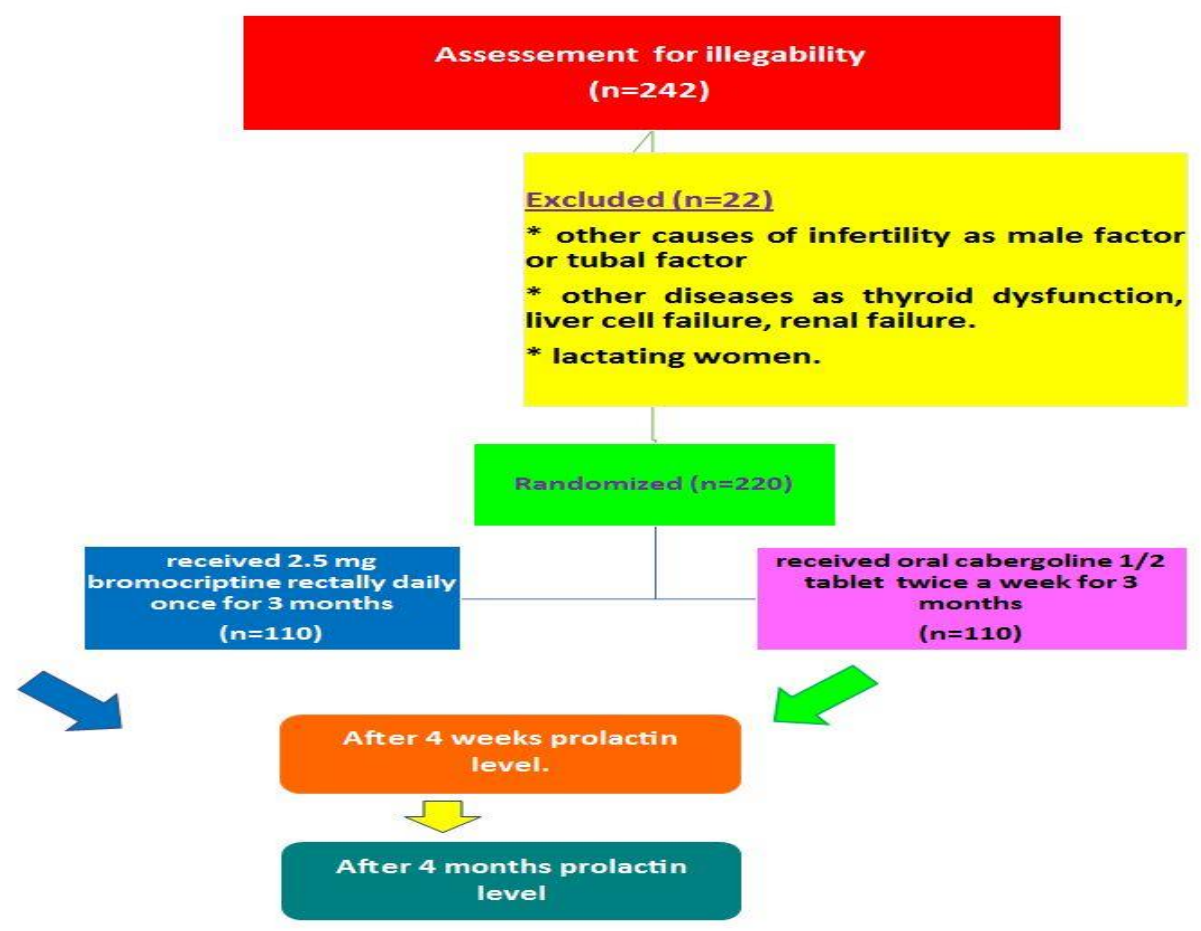

Fig (1) Study flow chart. Baseline data of all studied groups.

Table (1) Comparison of Age and gender distribution among studied groups.

\begin{tabular}{|c|c|c|c|c|c|c|c|}
\hline & \multirow{2}{*}{\multicolumn{2}{|c|}{$\begin{array}{c}\text { All cases } \\
\mathbf{N}=\mathbf{2 2 0}\end{array}$}} & \multirow{2}{*}{\multicolumn{2}{|c|}{$\begin{array}{c}\text { Bromocriptine group } \\
\mathrm{N}=110\end{array}$}} & \multirow{2}{*}{\multicolumn{2}{|c|}{$\begin{array}{c}\text { Cabergoline group } \\
\mathrm{N}=\mathbf{1 1 0}\end{array}$}} & \multirow{3}{*}{$\mathbf{p}$} \\
\hline & & & & & & & \\
\hline & mean & \pm SD & mean & \pm SD & mean & \pm SD & \\
\hline Age (years) & 27.8 & 5.6 & 28.3 & 5.8 & 27.4 & 5.4 & 0.266 \\
\hline BMI $\left(\mathrm{Kg} / \mathrm{m}^{2}\right)$ & 24.9 & 3.6 & 25.2 & 3.8 & 24.6 & 3.4 & 0.171 \\
\hline
\end{tabular}

The present study was conducted on 220 patients with symptoms suggesting hyperprolactinemia. Their mean age was 27.8 years. Their mean BMI was 24.9 $\mathrm{kg} / \mathrm{m} 2$.
No significant differences were found between bromocriptine and cabergoline groups regarding age (mean=28.3, 27.4 years respectively, >0.05); BMI (mean=15.2, 24.6 respectively; $\mathrm{p}>0.05$ ). 
Table (2) Comparison of complaint between all studied groups.

\begin{tabular}{|c|c|c|c|c|c|c|c|}
\hline & \multirow{2}{*}{\multicolumn{2}{|c|}{$\begin{array}{c}\text { All cases } \\
\mathbf{N}=\mathbf{2 2 0} \\
\end{array}$}} & \multirow{2}{*}{\multicolumn{2}{|c|}{$\begin{array}{c}\text { Bromocriptine group } \\
\mathbf{N}=110 \\
\end{array}$}} & \multirow{2}{*}{\multicolumn{2}{|c|}{$\begin{array}{c}\text { Cabergoline group } \\
\mathbf{N}=110\end{array}$}} & \multirow{3}{*}{ p } \\
\hline & & & & & & & \\
\hline & $\mathbf{N}$ & $\%$ & $\mathbf{N}$ & $\%$ & $\mathbf{N}$ & $\%$ & \\
\hline Primary infertility & 73 & $33.2 \%$ & 28 & $25.5 \%$ & 45 & $40.9 \%$ & \\
\hline Secondary infertility & 45 & $20.5 \%$ & 22 & $20 \%$ & 23 & $20.9 \%$ & \\
\hline Milk suppression & 42 & $19.1 \%$ & 23 & $20.9 \%$ & 19 & $17.3 \%$ & \\
\hline Galactorrhea & 33 & $15 \%$ & 22 & $20 \%$ & 11 & $10 \%$ & 0.124 \\
\hline Amenorrhea & 15 & $6.8 \%$ & 11 & $10 \%$ & 4 & $3.6 \%$ & \\
\hline Mastalgia & 11 & $5.0 \%$ & 3 & $2.7 \%$ & 8 & $7.3 \%$ & \\
\hline Irregular menses & 1 & $0.5 \%$ & 1 & $0.9 \%$ & 0 & $0 \%$ & \\
\hline
\end{tabular}

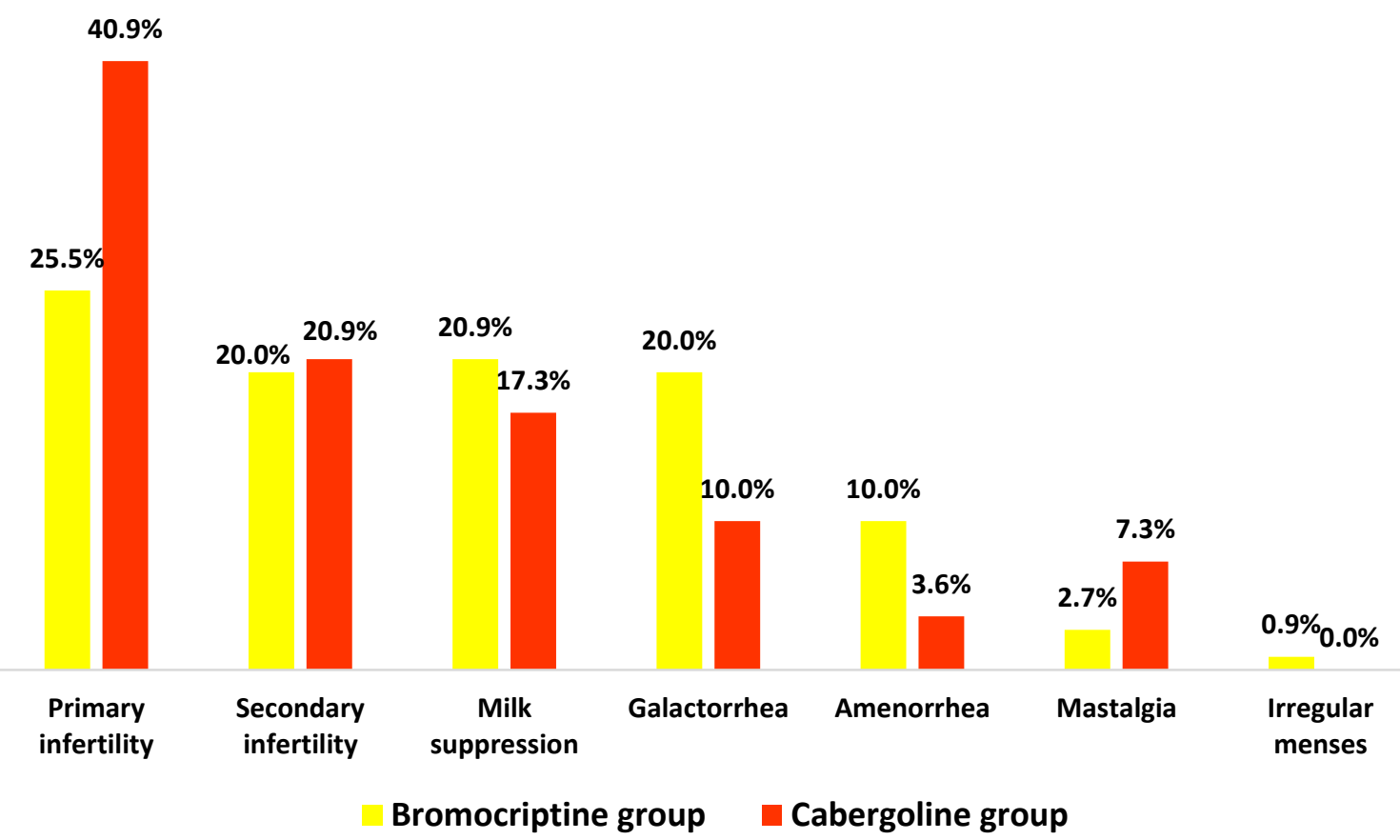

Fig (2) Complaint among all studied groups.

Most of studied cases complained of infertility (primary in $33.2 \%$, secondary in $20.5 \%$ ), milk suppression in $19.1 \%$, galactorrhea in $15 \%$, amenorrhea in $6.8 \%$, mastalgia in $5 \%$ and irregular menses in $0.5 \%$. No significant differences were present between both groups who received bromocriptine or cabergoline $(\mathrm{p}>0.05)$.

Table (3) Comparison of Prolactin level among studied groups.

\begin{tabular}{|c|c|c|c|c|c|}
\hline & \multirow{2}{*}{\multicolumn{2}{|c|}{$\begin{array}{c}\text { Bromocriptine group } \\
\mathbf{N}=\mathbf{1 1 0}\end{array}$}} & \multirow{2}{*}{\multicolumn{2}{|c|}{$\begin{array}{c}\text { Cabergoline group } \\
\mathrm{N}=110\end{array}$}} & \multirow{2}{*}{$\mathbf{P}^{1}$} \\
\hline & & & & & \\
\hline Prolactin level before treatment $(\mathrm{ng} / \mathrm{mL})$ & 40 & \pm 12.9 & 41 & \pm 11.3 & 0.727 \\
\hline $\begin{array}{l}\text { Prolactin level } 4 \text { weeks post treatment } \\
(\mathrm{ng} / \mathrm{mL}) \\
\mathbf{P}^{2}\end{array}$ & 16.5 & \pm 4.3 & 13 & \pm 4.1 & $<0.001$ \\
\hline
\end{tabular}

P1, comparison between bromocriptin and cabergoline groups; p2, comparison between before and 4 weeks after treatment in each group.
Comparing prolactin level pre and post treatment, there was significant decrease in prolactin level after treatment in Bromocriptine group (mean prolactin= 16.5 versus $40, \mathrm{p}<0.001$ ); as well as in Cabergoline group (mean prolactin $=11.3$ versus $41, \mathrm{p}<0.001$ ). 
Cabergoline group after treatment had significantly group $(\mathrm{p}<0.001)$. lower prolactin level when compared to Bromocriptine

Table (4) Comparison of percentage change in prolactin level among the studied groups.

\begin{tabular}{|c|c|c|c|c|c|}
\hline & \multirow{2}{*}{\multicolumn{2}{|c|}{$\begin{array}{c}\text { Bromocriptine group } \\
\mathrm{N}=110 \\
\end{array}$}} & \multirow{2}{*}{\multicolumn{2}{|c|}{$\begin{array}{c}\text { Cabergoline group } \\
\mathrm{N}=110 \\
\end{array}$}} & \multirow{3}{*}{$\mathbf{p}$} \\
\hline & & & & & \\
\hline & mean & \pm SD & mean & \pm SD & \\
\hline Change in prolactin level (\%) & 55 & \pm 15.3 & 64.9 & \pm 13.3 & $<0.001$ \\
\hline
\end{tabular}

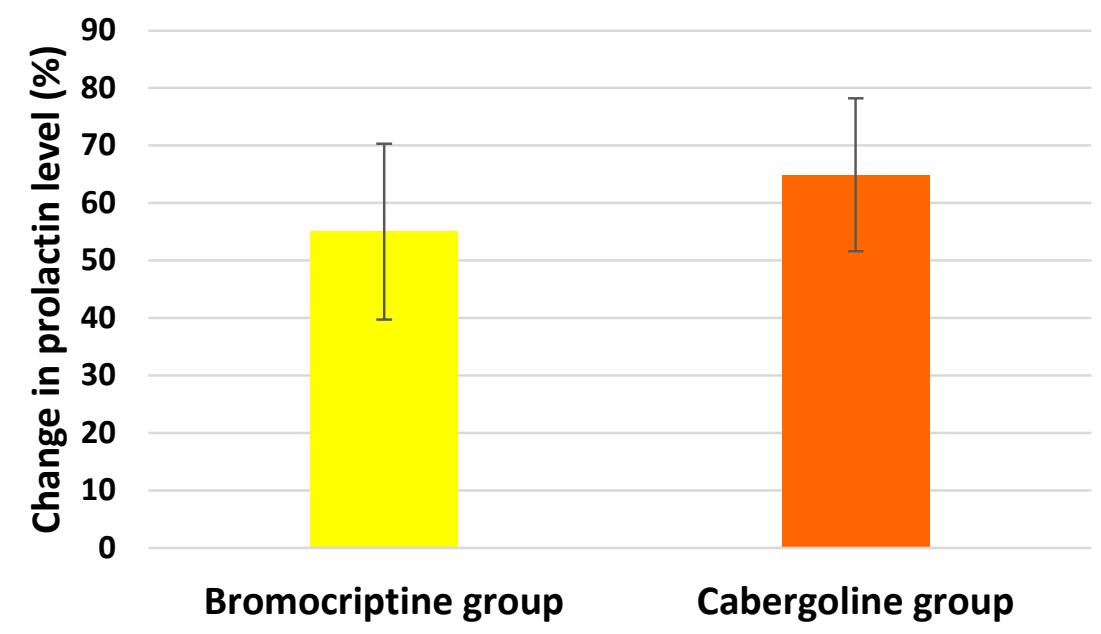

Fig (3) Percentage change in prolactin level among the studied groups.

Change in prolactin level after treatment comparing to baseline level was calculated, Cabergoline group showed significantly higher percentage change in prolactin level when compared to Bromocriptine group (mean percentage change $=64.9 \%$ versus $55 \%$, $\mathrm{p}<0.001)$.

Table (5) Comparison of recurrence of hyperprolactinemia among the studied groups.

\begin{tabular}{|c|c|c|c|c|c|}
\hline & \multirow{2}{*}{\multicolumn{2}{|c|}{$\begin{array}{c}\text { Bromocriptine group } \\
\mathrm{N}=103\end{array}$}} & \multirow{2}{*}{\multicolumn{2}{|c|}{$\begin{array}{c}\text { Cabergoline group } \\
\mathbf{N}=104\end{array}$}} & \multirow{3}{*}{$\mathbf{p}$} \\
\hline & & & & & \\
\hline & $\mathbf{N}$ & $\%$ & $\mathbf{N}$ & $\%$ & \\
\hline Recurrence & 13 & $12.6 \%$ & 13 & $12.5 \%$ & 0.979 \\
\hline
\end{tabular}

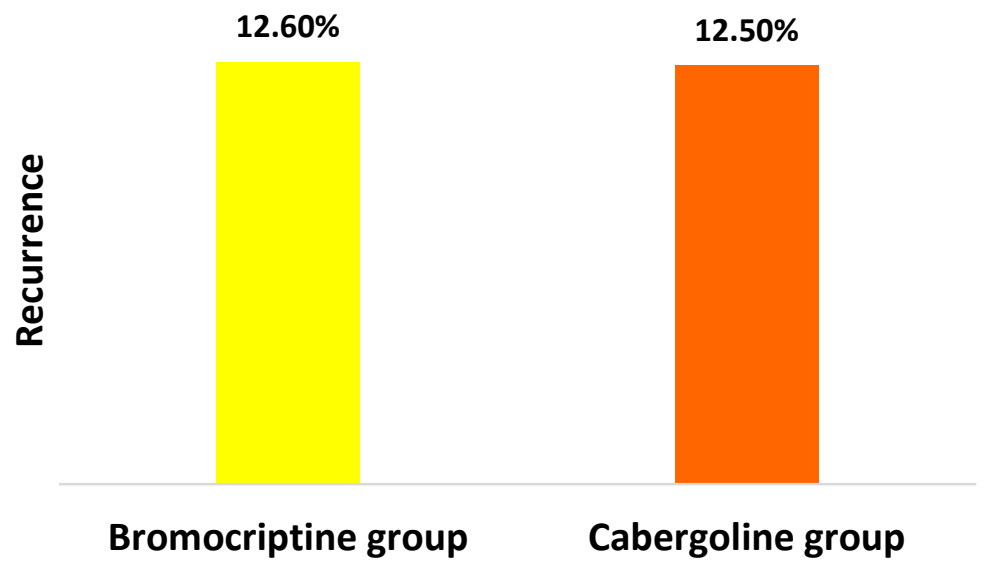

Fig (4) Recurrence of hyperprolactinemia among the studied groups.

After 4 months, prolactin level was assayed, no significant difference was found regarding recurrence of hyperprolactinemia among the studied groups (12.6\% versus $12.5 \%, \mathrm{p}>0.05)$. 
Table (6) Comparison of prolactin level 4 months after treatment in all, non-recurrent and recurrent cases.

\begin{tabular}{|c|c|c|c|c|c|}
\hline \multirow{2}{*}{16 weeks post treatment } & \multicolumn{2}{|c|}{ Bromocriptine group } & \multicolumn{2}{|c|}{ Cabergoline group } & \multirow[b]{2}{*}{$\mathbf{p}$} \\
\hline & mean & \pm SD & mean & \pm SD & \\
\hline All cases & 14 & 13.5 & 11.5 & 15.3 & 0.002 \\
\hline Non recurrent & 13.5 & 3.9 & 11.3 & 3.7 & $<0.001$ \\
\hline Recurrent & 46.8 & 14.8 & 53.4 & 13.7 & 0.137 \\
\hline
\end{tabular}

After 4 months, prolactin level was assayed, cabergoline group had significantly lower level when compared to bromocriptine group (11.5 versus 14 , $\mathrm{p}=0.002)$.

Stratifying cases into recurrent and non-recurrent hyperprolactinemia, revealed that those with non- recurrent hyperprolactinemia, cabergoline group had significantly lower level when compared to bromocriptine group (11.3 versus $13.5, \mathrm{p}<0.001)$.

While those with recurrent hyperprolactinemia, bromocriptine and cabergoline groups had nonsignificant difference in prolactin level at 4 months after treatment $(\mathrm{p}>0.05)$.

Table (7) Comparison of prolactin level 4 weeks and 4 months after treatment among the studied groups.

\begin{tabular}{|c|c|c|c|c|c|c|c|c|}
\hline & \multirow{2}{*}{\multicolumn{4}{|c|}{$\frac{\text { Bromocriptine group }}{\mathrm{N}=110}$}} & \multicolumn{4}{|c|}{ Cabergoline group } \\
\hline & & \multicolumn{2}{|c|}{$\mathbf{N}=110$} & & \multicolumn{4}{|c|}{$\mathrm{N}=110$} \\
\hline & \multicolumn{2}{|c|}{ Non recurrent } & \multicolumn{2}{|c|}{ Recurrent } & \multicolumn{2}{|c|}{ Non recurrent } & \multicolumn{2}{|c|}{ Recurrent } \\
\hline & mean & \pm SD & mean & \pm SD & mean & \pm SD & mean & \pm SD \\
\hline $\begin{array}{l}\text { Prolactin level } 4 \text { weeks post } \\
\text { treatment }(\mathrm{ng} / \mathrm{mL})\end{array}$ & 16.5 & 4.1 & 16.1 & 4.6 & 13.1 & 4.1 & 13.2 & 3.7 \\
\hline $\begin{array}{l}\text { Prolactin level } 4 \text { months post } \\
\text { treatment }(\mathrm{ng} / \mathrm{mL})\end{array}$ & 13.5 & 3.9 & 46.8 & 14.8 & 11.3 & 3.7 & 53.4 & 13.7 \\
\hline $\mathbf{P}$ & \multicolumn{2}{|c|}{$<0.001$} & \multicolumn{2}{|c|}{0.001} & \multicolumn{2}{|c|}{0.003} & \multicolumn{2}{|c|}{0.001} \\
\hline
\end{tabular}

p, comparison of prolactin level between 4 weeks and 4 months after treatment in each group.

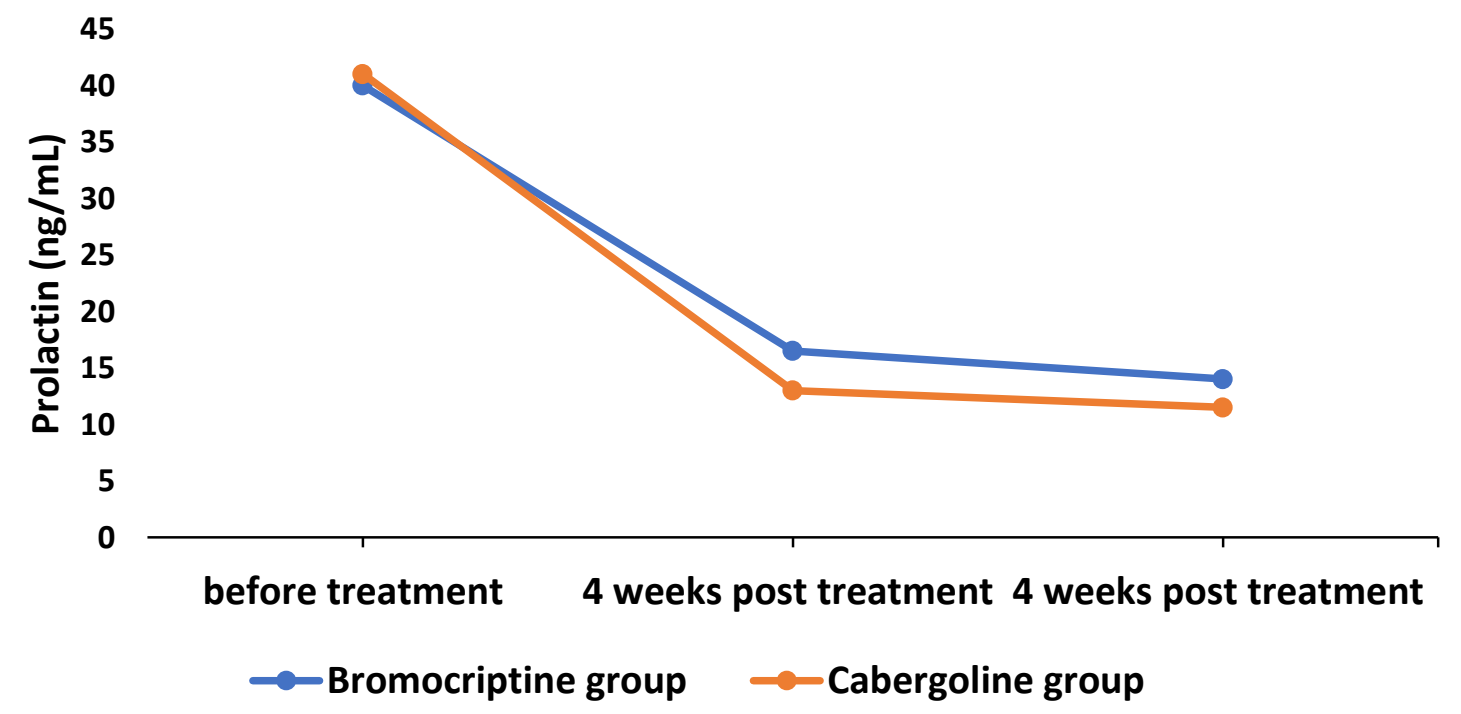

Fig (5) Change in prolactin level in studied groups throughout the study.

Stratifying cases according to recurrence in each treatment group, and comparing prolactin level 4 weeks and 4 months post treatment revealed that prolactin level decreased significantly in non-recurrent cases in both groups $(\mathrm{p}<0.001,=0.003$ respectively $)$. On the other hand, prolactin level increased significantly in recurrent cases in both groups $(p=0.001$ for each group). 
Table (8) Comparison of duration of treatment between studied groups.

\begin{tabular}{|c|c|c|c|c|c|}
\hline & \multirow{2}{*}{\multicolumn{2}{|c|}{$\begin{array}{c}\text { Bromocriptine group } \\
\mathrm{N}=110\end{array}$}} & \multirow{2}{*}{\multicolumn{2}{|c|}{$\begin{array}{c}\text { Cabergoline group } \\
\mathrm{N}=110 \\
\end{array}$}} & \multirow{3}{*}{$\mathbf{p}$} \\
\hline & & & & & \\
\hline & mean & \pm SD & mean & \pm SD & \\
\hline Duration of treatment (weeks) & 4.8 & 1.4 & 4.7 & 1.5 & 0.579 \\
\hline
\end{tabular}

Mean treatment duration in bromocriptine and cabergoline groups was about one month, with no significant difference between both groups $(\mathrm{p}>0.05)$.

Table (9) Comparison of prolactin level normalization after treatment between studied groups.

\begin{tabular}{|c|c|c|c|c|c|c|}
\hline & & \multicolumn{2}{|c|}{$\begin{array}{c}\text { Bromocriptine group } \\
\mathrm{N}=110\end{array}$} & \multicolumn{2}{|c|}{$\begin{array}{c}\text { Cabergoline group } \\
\mathrm{N}=110\end{array}$} & \multirow{2}{*}{$\mathbf{p}$} \\
\hline & & $\mathbf{N}$ & $\%$ & $\mathbf{N}$ & $\%$ & \\
\hline \multirow[t]{3}{*}{ Normalization of prolactin level after } & 4 weeks & 57 & $51.8 \%$ & 69 & $62.7 \%$ & 0.105 \\
\hline & 4-8 weeks & 39 & $35.5 \%$ & 29 & $26.4 \%$ & 0.126 \\
\hline & 8-12 weeks & 7 & $6.4 \%$ & 6 & $5.5 \%$ & 0.761 \\
\hline
\end{tabular}

Both groups showed non-significant differences for duration of prolactin level to be normalized. Although those received cabergoline had non significantly higher frequency of normalized females after 4 weeks when compared to Bromocriptine group ( $\mathrm{p}>0.05)$.

\section{Outcome of studied groups}

Table (10) Comparison of side effects between all studied groups.

\begin{tabular}{|c|c|c|c|c|c|}
\hline & \multicolumn{2}{|c|}{ Bromocriptine group } & \multicolumn{2}{|c|}{ Cabergoline group } & \multirow{3}{*}{$\mathbf{p}$} \\
\hline & \multicolumn{2}{|c|}{$\mathrm{N}=110$} & \multicolumn{2}{|c|}{$\mathrm{N}=110$} & \\
\hline & $\mathbf{N}$ & $\%$ & $\mathbf{N}$ & $\%$ & \\
\hline All side effects & 37 & $33.6 \%$ & 36 & $32.7 \%$ & 0.886 \\
\hline Constipation & 15 & $13.6 \%$ & 0 & $0 \%$ & $<0.001$ \\
\hline Rectal irritation & 18 & $16.4 \%$ & 0 & $0 \%$ & $<0.001$ \\
\hline Abdominal cramps & 11 & $10 \%$ & 0 & $0 \%$ & 0.001 \\
\hline Diarrhea & 2 & $1.8 \%$ & 0 & $0 \%$ & 0.498 \\
\hline Headache & 1 & $0.9 \%$ & 9 & $8.2 \%$ & 0.010 \\
\hline Dizziness and fainting & 0 & $0 \%$ & 9 & $8.2 \%$ & 0.003 \\
\hline Nausea and vomiting & 0 & $0 \%$ & 6 & $5.5 \%$ & 0.029 \\
\hline Hypotension & 0 & $0 \%$ & 2 & $1.8 \%$ & 0.498 \\
\hline Bloating & 0 & $0 \%$ & 11 & $10 \%$ & 0.001 \\
\hline
\end{tabular}

Bromocriptine group was significantly associated with constipation, rectal irritation, abdominal cramps $(\mathrm{p}<0.001,<0.001,=0.001$ respectively).

Cabergoline group was significantly associated with headache, dizziness, fainting, nausea, vomiting, bloating ( $\mathrm{p}=0.01,0.003,0.029,0.001$ respectively).
Diarrhea, hypotension and noncompliance did not differ between both groups ( $\mathrm{p}>0.05)$.

Mean onset of side effects of bromocriptine and cabergoline groups was about one month, with no significant difference between both groups $(\mathrm{p}>0.05)$.

Table (11) Comparison of onset of side effects between studied groups.

\begin{tabular}{|c|c|c|c|c|c|}
\hline \multirow[b]{4}{*}{ Onset of side effects (weeks) } & \multirow{2}{*}{\multicolumn{2}{|c|}{$\begin{array}{c}\text { Bromocriptine group } \\
\mathrm{N}=110 \\
\end{array}$}} & \multirow{2}{*}{\multicolumn{2}{|c|}{$\begin{array}{c}\text { Cabergoline group } \\
\mathrm{N}=110 \\
\end{array}$}} & \multirow{3}{*}{$\mathbf{p}$} \\
\hline & & & & & \\
\hline & mean & \pm SD & mean & \pm SD & \\
\hline & 4.2 & \pm 1.3 & 3.4 & \pm 1.1 & 0.094 \\
\hline
\end{tabular}

No significant differences were found between both groups regarding onset of side effects. 


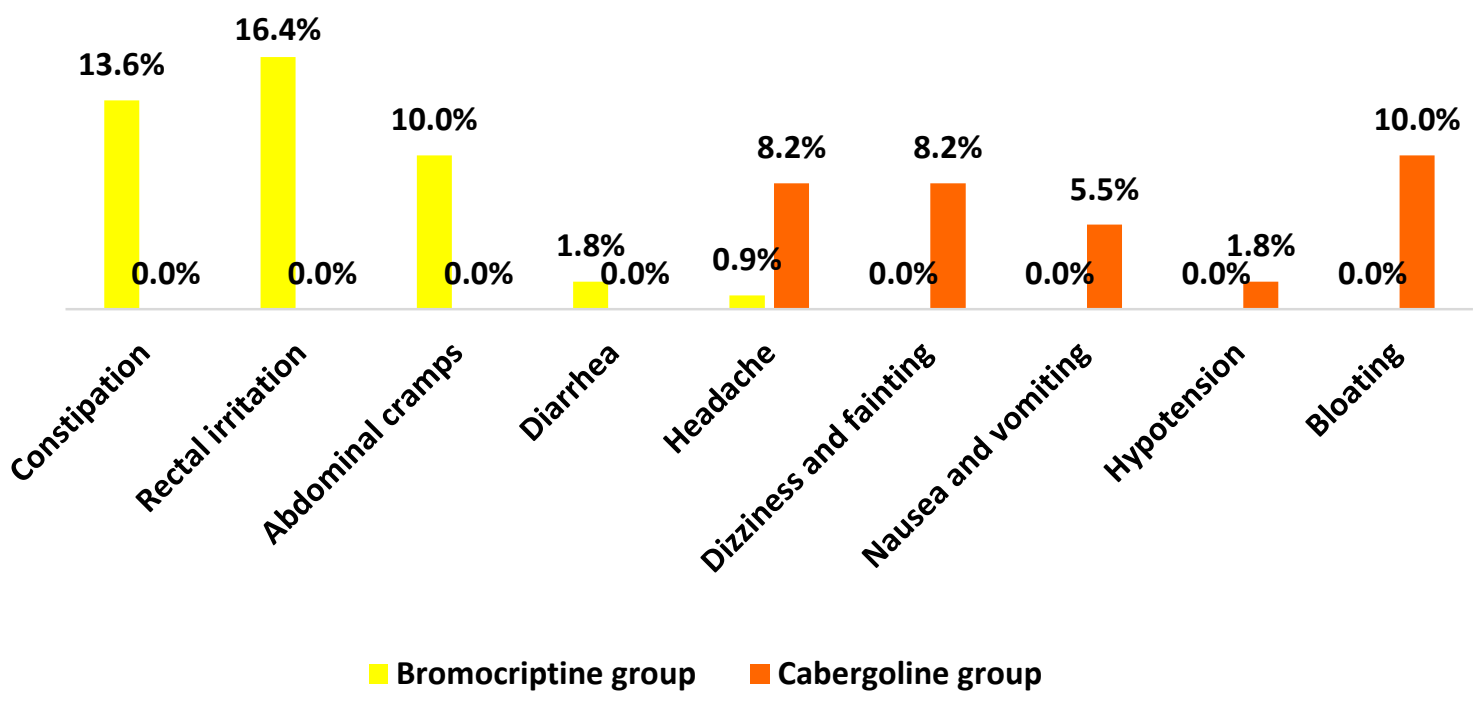

Fig (6) Side effects in all studied groups.

Table (12) Comparison of tolerability of the patients between all studied groups.

\begin{tabular}{|c|c|c|c|c|c|}
\hline \multirow[b]{4}{*}{ Non compliance } & \multirow{2}{*}{\multicolumn{2}{|c|}{$\begin{array}{c}\text { Bromocriptine group } \\
\mathrm{N}=110\end{array}$}} & \multirow{2}{*}{\multicolumn{2}{|c|}{$\begin{array}{c}\text { Cabergoline group } \\
\mathrm{N}=110 \\
\end{array}$}} & \multirow{3}{*}{$\mathbf{p}$} \\
\hline & & & & & \\
\hline & $\mathbf{N}$ & $\%$ & $\mathbf{N}$ & $\%$ & \\
\hline & 7 & $6.4 \%$ & 6 & $5.5 \%$ & 0.775 \\
\hline
\end{tabular}

During the whole period of the study, some cases dropped out, 7 cases were dropped out from
Bromocriptine group and 6 cases were dropped out from Cabergoline group.

No significant differences were found between both groups regarding tolerability of the patients $(p>0.05)$.

Table (13) Comparison of reproductive outcome among the studied groups.

\begin{tabular}{|c|c|c|c|c|c|}
\hline & \multicolumn{2}{|c|}{ Bromocriptine group } & \multicolumn{2}{|c|}{ Cabergoline group } & \multirow{3}{*}{$\mathbf{p}$} \\
\hline & $\mathbf{N}=$ & & $\mathbf{N}=$ & & \\
\hline & $\mathbf{N}$ & $\%$ & $\mathbf{N}$ & $\%$ & \\
\hline pregnancy & 23 & $20.9 \%$ & 17 & $15.5 \%$ & 0.294 \\
\hline
\end{tabular}

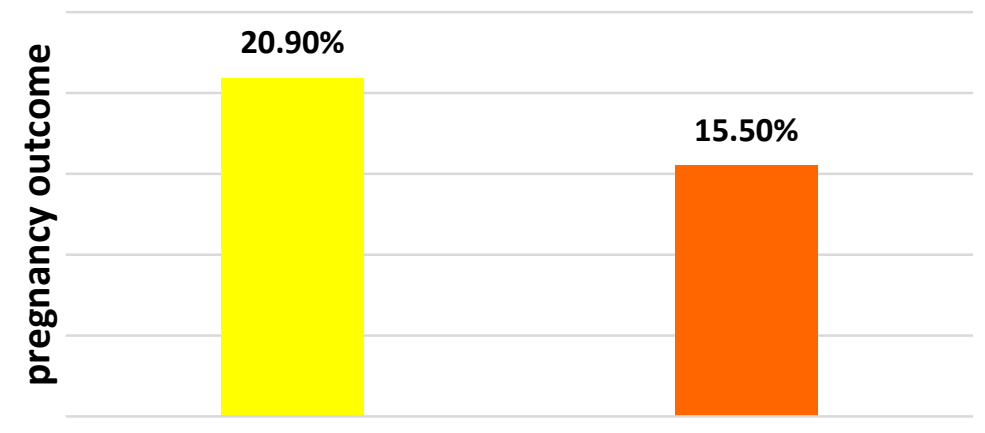

Bromocriptine group Cabergoline group

Fig (7) Reproductive outcome among the studied groups.

Among those received Bromocriptine, 20.9\% get pregnancy, while among those received Cabergoline, $15.5 \%$ get pregnancy, with no significant differences between both groups $(\mathrm{p}>0.05)$. 


\section{Discussion}

Prolactin is a polypeptide chemical that is integrated in the foremost pituitary organ and emitted in a pulsatile way. It assumes focal part in an assortment of conceptive capacities and lactation. Prolactin discharge in people relies upon physiological state and fluctuates in light of various boosts [12].

Hyperprolactinemia is a typical endocrinological problem; it very well may be physiological, obsessive or idiopathic in birthplace. The dominating physiological result of hyperprolactinemia is concealment of pulsatile GnRH. The clinical indications of conditions shift essentially relying upon the age and the sex of the patient. In ladies, it often prompts gonadal brokenness including ovulatory problem, feminine aggravations, galactorrhea and fruitlessness [5].

Bromocriptine methylate, as a dopamine agonist, is being utilized for treatment of hyperprolactinemia since quite a while. It is end up being compelling in causing emotional decrease of serum prolactin after its oral use. In any case, it every now and again causes unfavorable results whenever given orally like queasiness, regurgitating, weakness, cerebral pains, tipsiness, and faintness in $50-70 \%$ of ladies (19). Non-oral methodology may take out the majority of these manifestations [12].

The non-oral courses of organization of medications evade decimation or inactivation by the $\mathrm{pH}$ or enzymatic action of the stomach or digestive tract, kill stomach bothering, and discard drug annihilation by entryway dissemination by initial pass through the liver. Besides, these courses are helpful for patients who might be not able or reluctant to swallow prescription and it is a viable course in the treatment of patients with heaving scenes. For fundamental impacts, the mucous films of the rectum license the ingestion of numerous dissolvable medications [14].

Cabergoline is an agonist explicit to the D2 dopamine receptor and has a long half-life, permitting its week after week organization [7]. In view of these attributes and on a few relative examinations, cabergoline has been viewed as better than bromocriptine for the treatment of hyperprolactinemia and compelling in numerous patients' impervious to bromocriptine [4]. To demonstrate this speculation, we have planned a similar report that assessed rectal bromocriptine versus carbergoline in the treatment of hyperprolactinemia.

This investigation was directed on 220 hyperpractinemic patients experiencing gonadal brokenness, galactorrhea, feminine inconsistencies, mastalgia and barrenness, this examination was done at Benha college emergency clinic outpatient centers at the period from April 2018 to January 2020.

All the patients had serum prolactin level over 25 $\mathrm{ng} / \mathrm{dl}$ at season of treatment and partitioned haphazardly (automated) into two gatherings the primary gathering got bromocriptine $2.5 \mathrm{mg}$ rectally day by day as long as 3 months. The subsequent gathering got $0.5 \mathrm{mg}$ of oral cabergoline every 3 days as long as 3 months. serum prolactin was tested following a month and 4 months from the earliest starting point of the treatment the patients were notices for the achievement of the treatment as respect the standardization of serum prolactin level, reclamation of gonadal capacity, milk concealment, pregnancy and bearableness.

This examination is viewed as one of the main investigations to survey rectal bromocriptine versus carbergoline in the treatment of hyperprolactinemia which renders correlation between its outcomes and different explores troublesome. In any case, numerous different analysts examined the job oral bromocriptine versus oral cabergoline in the treatment of hyperprolactinemia.

The adequacy of bromocriptine has been assessed in past examinations which showed the advantage of bromocriptine in bringing down serum prolactin level and reestablishing ordinary feminine draining and calming galactorrhea in most of patients, [19], which are in concurrence with the aftereffects of this investigation :The level of decrease of serum prolactin level acquired in the current examination in bromocriptine gathering $(82.2 \%)$ that was better than [12] $(69.2 \%)$ and near the estimation of $83 \%$ announced by [15].

The PRL standardization rate as per (12) where the achievement rates were 59\%, and $67.7 \%$, individually. As to, the current outcomes are in concurrence with a few different examinations showing the adequacy of $\mathrm{CAB}$ treatment in hyperprolactinemia. Our level of achievement $(87.4 \%)$ in accomplishing typical PRL levels in the $\mathrm{CAB}$ bunch falls inside the edges of 82-93 $\%$ accomplishment of different examinations. At the point when we analyzed the $\mathrm{CAB}$ and $\mathrm{BRC}$ gatherings, we distinguished an essentially higher achievement rate on recuperation of hyperprolactinemia in the CABtreated gathering, which was as per past outcomes [6]. These discoveries plainly show that $\mathrm{CAB}$ is better than BRC in normalizing PRL levels.

In our investigation among the individuals who got Bromocriptine, $20.9 \%$ get pregnancy, while among those got Cabergoline, $15.5 \%$ get pregnancy, with no critical contrasts between the two gatherings ( $p>0.05)$.

S.M.O'Sullivan [14] found that Treatment with a DA reestablishes ovulation in over $90 \%$ of ladies with prolactinoma and anovulatory fruitlessness and their examination affirms that DA use during the initial five weeks of pregnancy is protected and not related with an expansion in the quantity of unsuccessful labors, intrinsic contortions or other unfavorable neonatal and pregnancy results past populace typical reaches.

R.Krysiak [10] found that Both bromocriptine and cabergoline, the two most ordinarily endorsed dopaminergic specialists, share numerous attributes and unfavorable impacts. Cabergoline is, notwithstanding, liked, especially in patients with prolactinoma, because of a more prominent remedial effectiveness, a superior resilience and thusly, more noteworthy adherence to 
treatment and, at last, in light of a more advantageous organization routine. cabergoline is controlled more than once week after week, while bromocriptine requires dosing each 8-24 hr 9, Compared with bromocriptine, cabergoline has a lower liking for D1 receptors and animates 5HT2B receptors stronger.in our examination we expected to oversee bromocriptine rectally once just every day and this had improved the decency to bromocriptine.

A.Arduc [2] demonstrated that $\mathrm{CAB}$ was more viable in controlling manifestations related with prolactin chemical overabundance, normalizing serum PRL levels (87.4 versus $41.4 \%, \mathrm{p}=0.029)$, contrasted with BRC in a comparable term of treatment.

In our investigation Treatment with $\mathrm{CAB}$ had altogether lower PRL level when contrasted with BRC bunch at about a month and 4 months. gathering (mean rate change $=64.9 \%$ versus $55 \%, \mathrm{p}<0.001)$.

As per term of treatment the two gatherings demonstrated non-huge contrasts for length of prolactin level to be standardized. In contrasting the capacity of $\mathrm{BRC}$ and $\mathrm{CAB}$ to treat side effects identified with hyperprolactinemia, we found that $\mathrm{CAB}$ and $\mathrm{BRC}$ are similarly useful in reestablishing ordinary menses, alleviating galactorrhea, mitigating mastalgia and improve the richness. Following 4 months, prolactin level was tested, cabergoline bunch had essentially lower level when contrasted with bromocriptine gathering (11.5 versus $14, \mathrm{p}=0.002)$.

Delineating cases into intermittent and nonrepetitive hyperprolactinemia, uncovered that those with non-repetitive hyperprolactinemia, cabergoline bunch had essentially lower level when contrasted with bromocriptine gathering (11.3 versus $13.5, \mathrm{p}<0.001)$. While those with intermittent hyperprolactinemia, bromocriptine and cabergoline bunches had noncritical distinction in prolactin level at 4 months after treatment $(\mathrm{p}>0.05)$.

M.Teixeira [18] found a low rate $(35.2 \%)$ of withdrawal of DA treatment in subjects with prolactinoma. Females, microprolactinomas, patients with lower beginning serum PRL levels and with longer treatment span all had a higher likelihood of seeing their treatment ended. Reduction rates with bromocriptine range from 7 to $44 \%$, though abatement rates with cabergoline shift from 17 to $46 \%$, or even $69 \%$ if just microprolactinomas are considered.

However, H.Y.Huang [9] discovered various outcomes, recommending that under the reason of looking after normoprolactinemia, patients with decreased cabergoline admission to the most reduced portion before withdrawal had a lower repeat rate than patients taking higher cabergoline dosages at the hour of withdrawal.

Y.Aydin [3] indicated that in administration of mastalgia carried on 140 ladies with premenstrual mastalgia were selected the examination the positive reaction rates to treatment were comparative (BRC $66.6 \%$ and $\mathrm{CAB} 68.4 \%$ ). The agony decrease rates for every month were additionally comparable. Also, the agony decrease rate was greatest in the second month of treatment for the two gatherings.

In our examination 11 ladies and 8 ladies with mastalgia treated by $\mathrm{BRC}$ and $\mathrm{CAB}$ demonstrated improvement inside about a month with negligible antagonistic results. There was no relationship between's the gauge bosom torment score and prolactin level however post-treatment torment decrease was very much corresponded with prolactin level.

The quantity of patients experiencing unfavorable impact in the current investigation was lower in the cabergoline gathering $(32.7 \%)$ contrasted and the bromocriptine gathering (33.6\%). There were no lower gastro intestinal manifestations in the cabergoline bunch contrasted and the bromocriptine gathering. Yet, focal and upper gastrointestinal side effects were higher in $\mathrm{CAB}$ gathering. Our outcomes are like those got in the past examinations that indicated likewise less unfriendly impacts with cabergoline and higher frequency with bromocriptine [4].

A.Arduc [2] indicated that $24(5.3 \%)$ patients in the $\mathrm{CAB}$ gathering and $14(29.1 \%)$ in the BRC bunch revealed results $(p<0.001)$. Eight out of 450 patients in the $\mathrm{CAB}$ bunch experienced blockage, nine migraine, and seven discombobulation. Cerebral pain was accounted for in four patients, stomach distress in four, unsteadiness in five, and drowsiness in one out of 48 patients in the BRC bunch which are more uncommon than our investigation.

In our investigation BRC bunch was essentially connected with blockage, rectal aggravation, stomach cramps $(\mathrm{p}<0.001,<0.001,=0.001$ respectively). While $\mathrm{CAB}$ bunch was altogether connected with migraine, wooziness, blacking out, queasiness, spewing, swelling $(\mathrm{p}=0.01,0.0$

\section{Conclusion}

Bromocriptine and cabergoline are both successful in the treatment of hyperprolactinemia with rebuilding of gonadal capacity, richness easing of mastalgia and milk concealment. Utilization of rectal bromocriptine decline essentially the focal and upper gastrointestinal unfriendly impact and decency in contrast with oral Bromocriptine. Cabergoline has prevalent impact in diminishing prolactin level than rectal bromocriptine. No critical distinction was found with respect to repeat of hyperprolactinemia after treatment. Bromocriptine bunch was fundamentally connected with stoppage, rectal disturbance, stomach cramps. Cabergoline bunch was altogether connected with migraine, wooziness, blacking out, queasiness, heaving, swelling. No huge contrasts were found between the two gatherings with respect to bearableness of the patients, regenerative result.

\section{References}

[1] A .Al-Huseynei, I.H. Mahmood, Z.S. Al-Jubori, Comparison of the effects of cabergoline and bromocriptine in women with hyperprolactinemic 
amenorrhea. Middle East Fertile Soc J , Vol.13, PP.33-88,2015.

[2] A.Arduc, F.Gokay, S.Isik, Retrospective comparison of cabergoline and bromocriptine effects in hyperprolactinemia: a single center experience. J Endocrinol Invest, Vol. 38, PP. 447$453,2015$.

[3] Y.Aydin, A.Atis, S.Kaleli, S.Uludağ, N.Goker, Cabergoline versus bromocriptine for symptomatic treatment of premenstrual mastalgia: a randomised, open-label study. European Journal of Obstetrics \& Gynecology and Reproductive Biology, Vol.150(2), pp.203-206,2010.

[4] C.L. Boguszewski, C.M.C. dos Santos, K.S. Sakamoto, L.C.Marini, A.M. de Souza, M.Azevedo, A comparison of cabergoline and bromocriptine on the risk of valvular heart disease in patients with prolactinomas. Pituitary, vol.15(1), pp.44-49,2012.

[5] A.Capozzi, G.Scambia, A.Pontecorvi, S.Lello, Hyperprolactinemia: pathophysiology and therapeutic approach. Gynecological Endocrinology, Vol.31(7), pp.506-510,2015.

[6] A.G. Edlow, E.R.Norwitz, Endocrine diseases of pregnancy. In Yen and Jaffe's Reproductive Endocrinology, Vol.5(3), PP. 662-708, 2019.

[7] A.Faje, P.Chunharojrith, J.Nency, B.M.Biller, B.Swearingen, A.Klibanski, Dopamine agonists can reduce cystic prolactinomas. The Journal of Clinical Endocrinology \& Metabolism, Vol. 101(10), pp.3709-3715,2016.

[8] J .Hu, X. Zheng, W. Zhang, H.Yang, Current drug withdrawal strategy in prolactinoma patients treated with cabergoline: a systematic review and metaanalysis. Pituitary, Vol. 18(5), PP.745-751,2015.

[9] H.Y.Huang, W.Zhai, H. Tang, Cabergoline for the treatment of bromocriptine-resistant invasive giant prolactinomas. Endocrine, Vol. 62, PP. 464469,2018 .

[10] R.Krysiak, B.Okopien, Different effects of cabergoline and bromocriptine on metabolic and cardiovascular risk factors in patients with elevated prolactin levels. Basic \& Clinical Pharmacology \& Toxicology, Vol.116(3), pp.251-256,2015.

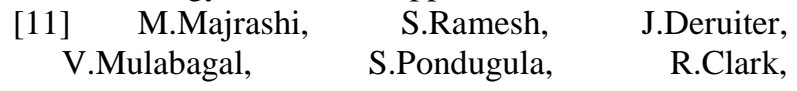

M.Dhanasekaran, Multipotent and Poly-therapeutic Fungal Alkaloids of Claviceps purpurea. In Medicinal Plants and Fungi: Recent Advances in Research and Development, Springer, Singapore, Vol.8(3), PP. 229-252,2017.

[12] A.Majumdar, N.S.Mangal, Hyperprolactinemia. Springer, New Delhi., In Principles and Practice of Controlled Ovarian Stimulation in ART, Vol.54, PP. 319-328,2015.

[13] S .Malik, S.Z. Hussain, R. Basit, N. Idress, A. Habib, M. Zamant, Demographic characteristics, presentations and treatment outcome of patients with prolactinoma. J Ayub Med Coll Abbottabad. Jul-Sep , Vol. 26 (3), PP.269-74 ,2014.

[14] S.M.O'Sullivan, M.T. Farrant, C.M. Ogilvie, A.J. Gunn, S.R.Milsom, An observational study of pregnancy and post-partum outcomes in women with prolactinoma treated with dopamine agonists. Australian and New Zealand Journal of Obstetrics and Gynaecology, Vol. 48(5), pp. 314-332,2019.

[15] R.W. Rebar, W.H. Catherino, Reproductive endocrinology and infertility. Goldman-Cecil Medicine. 25th ed. Philadelphia, PA: Elsevier Saunders, Vol.88, pp.85-97,2016.

[16] S.Samson, S.Ezzat, AACE/ACE disease state clinical review: dopamine agonists for hyperprolactinemia and the risk of cardiac valve disease. Endocrine Practice, Vol. 20(6), pp.608$616,2014$.

[17] V.G. Sita, P.Vavia, Bromocriptine nanoemulsion-loaded transdermal gel: optimization using factorial design, in vitro and in vivo evaluation. AAPS PharmSciTech, Vol. 21(3), pp.80-82,2017.

[18] M.Teixeira, P. Souteiro, D.Carvalho, Prolactinoma management: predictors of remission and recurrence after dopamine agonists withdrawal. Pituitary, Vol.20, 464-470,2017.

[19] N.A. Tritos, A.Klibanski, Prolactin and its role in human reproduction. In Yen and Jaffe's Reproductive Endocrinology , Vol.65, PP. 5874,2019 ,

[20] M.Vander Borght, C.Wyns, Fertility and infertility: Definition and epidemiology. Clinical biochemistry, Vol.62, PP.2-10,2018. 